\title{
A Case Study of Trade Secret Legal Risk Management
}

\author{
Xing Yuxia ${ }^{1, *}$ \\ ${ }^{1}$ Civil and Commercial Law Institute, Shandong University of Political Science and Law, Jinan, Shandong, 250014, \\ China. \\ *Corresponding author. Email: f5150@126.com
}

\begin{abstract}
According to the "Special 301 Report" of the United States, ZTE incident was caused by violations of US sanctions against Iran and allegedly stealing US trade secrets, highlighting the importance of legal and compliance risk management of Chinese trade secrets. The "Special 301 Report" has a special discussion on the issue of trade secrets, and has certain reference value for the management and protection of Chinese trade secrets at the legal and political risk. On the basis of rationally seeing the "Special 301 Report", raising the protection of trade secrets to a strategic level of national security, China should adhere to China's attitude and do a good job in the "three-in-one" trial procedure as the core of China's socialist political characteristics of trade secrets and compliance management work for Chinese companies. The legal risk of trade secrets in international trade would be well controlled.
\end{abstract}

Keywords: Trade Secret Management, Special 301 Report, Legal Risk, China Plan

\section{INTRODUCTION}

According to the "Special 301 Intellectual Property Clause" of the US Comprehensive Trade and Competition Law, the Office of the US Trade Representative has issued the "Special 301 Report" for 32 consecutive years from 1989 to 2020.The report conducts an annual evaluation of the state of intellectual property legislation and law enforcement protection in countries or regions with a trading partnership with the United States, and develops corresponding action plans to promote improvement. The report has had an important impact on the development of the rule of law in intellectual property, including the rule of law in trade secrets. Compared with other intellectual property rights such as patents, trade secrets are described by the Special 301 Report as "the core assets of the enterprise", which is enough to show its important position.

At the China ZTE incident, because its lawyer leaked their trade secrets (whatever it is legal), resulting in the reconciliation of the company with the United States by paying huge fines and deposits in June-July 2018.

How to manage and protect the enterprise's trade secrets legal risk is the most important question.

\section{THE CASE OF ZTE}

In the ZTE incident, ZTE knows that Sino-US trade disputes continue to occur. It is also known that the US FBI has been investigating ZTE and Huawei, and that its legal counsel, Yablon, has a 10-month short-term experience in Huawei. These are actually enough to remind the alarm for the ZTE company to employ this lawyer. However, unfortunately, ZTE has over-confidenced the mindset of its localization of American subsidiaries, and through this lawyer, ZTE itself was sent to the guillotine.

We also believe that ZTE, as a large state-owned enterprise, has sound legal risk management and control capabilities, including the restraint and regulation of the lawyer's confidential work, but ZTE, which was exposed by the media and ridiculed by Trump in the United States, used 1 million yuan to remunerate. The smuggling of the confidentiality agreement to deal with its own international business risks can only show that ZTE clearly underestimates the complex intertwining of the international economic field and the political field, and is too superstitious to "good and basic professional ethics".

In the process of going global, Chinese companies should be able to strengthen the use of local core personnel such as legal affairs, finance, and technology. When they are forced to hire local foreigners, they must be aware of the background of foreign personnel, the scope of their employment, and the scope of knowing the secrets of enterprises. Do the appropriate due diligence work, formulate reasonable and feasible confidentiality measures, and strictly implement and continue to do preventive work. It is not so much that trade secrets are the blood of enterprises. It is better to say that trade secrets are the nerves of enterprises. The lack of blood can be transfused to maintain the normal operation of the body within a certain period of time, but the lack of nerves can immediately set the body in the "materialized" state of numbness. And can't be recreated. Enterprises should recognize the "nerve" nature of trade secrets and do legal risk management and control of trade secrets.

Maybe ZTE has no macro control over many factors, but the US lawyer hired by ZTE to disclose their trade secrets by reporting to the US FBI is the key to the completion of the entire incident. On the one hand, the United States has protected the reporting lawyers through the immunity terms in the Trade Secret Protection Act of 2016; on the other hand, the Special 301 Report, which is based on the 
protection needs of the interests of American business secret owners and maximizes their interests, continue to raise questions and negative comments to Chinese trade secret legislative and law enforcement issues.

Need to follow its own hardware. The international environment and political confrontation are external factors for enterprises, and enterprises cannot change them. The only thing that can be controlled by enterprises is the basic work of risk management and control of enterprises themselves. Chinese enterprises can learn from the lessons of the ZTE incident, raise the protection of trade secrets and legal risks to the first-level readiness of enterprises, strengthen the basic work of legal protection and the guarantee of enterprise program management. When hiring legal, technical, financial and other related personnel, it is necessary to review their background, ethnic background, background of beliefs and national background, and try to avoid employing personnel from the above-mentioned fields in countries where trade disputes may occur with China.

ZTE is not successful in the management and protection of trade secrets, whatever these trade secrets are legal, and this case can bring us much thinking.

\section{THE COMPARATIVE ANALYSIS OF SPECIAL 301 REPORT, CHINA LEGIS- LATION AND ENFORCEMENT ON TRADE SECRETS}

Since the "Special 301 Report" in 2013, the United States believes that theft of trade secrets threatens US national security and the US economy, weakens the United States' global development prospects, and puts US employment at risk. Therefore, the study of trade secret legislation and law enforcement status in trading partner countries and regions has become an important part of the Special 301 Report.

In particular, after Trump became the US president in January 2017, the US trade policy turned a big turn and began to launch a 301 investigation on China on the grounds of protecting national security. The total value of the products involved was gradually upgraded from 50 billion US dollars to $\$ 250$ billion. As the threats did not work in China, the United States turned to the threat of trade sanctions into tangible sanctions.

This fully explains the reason why trade secrets are increasingly valued in the Special 301 Report. In addition to the maximization of the international intellectual property rights of American trade secret rights holders, the US government headed by Trump has regarded it as a national strategic consideration for the security level of the US realism.

In response to the above allegations of the Special 301 Report, China has the different opinion:

First, companies have the right to require foreign investors or partners to exchange their business secret technology for cooperation and enter the Chinese market.

At present, China is in a period of rapid economic devel- opment. It is no longer the urgent demand for foreign capital in the 1980s and 1990s. Instead, high-end technology and advanced management models have increasingly become bottlenecks for China's economic development. With China's growing power, international scholars have also given high hopes for China's active participation in international organizations. For example, Peter A. Petri (2019) believes that after the Trump administration in the United States was hot and quit, China should join the Trans-Pacific Partnership Comprehensive Progressive Agreement, which came into effect on December 30, 2018 , to strengthen intellectual property protection in respect of weaker legal protection of trade secrets [1]. In this context, all kinds of Chinese enterprises, including state-owned enterprises and private enterprises, have the right to choose the right partners according to their actual needs under the full protection of the country: they are willing to exchange their high-end technology and advanced management mode. And the partners who enter the Chinese market, which are the autonomous behaviors determined by the free competition of the market economy. These partners have also obtained the huge dividend they deserve from China's rapid development. The United States has no reason to use its value standard of domestic law to judge and discredit the legitimate business practices of Chinese companies.

Second, China has its own legislative, judicial and law enforcement system and should adhere to sustainable development.

First of all, at the legislative level, the Anti-Unfair Competition Law, which was revised and implemented in 2018 and 2019, has done a lot of legislative improvement work in accordance with the national development reality in terms of the basic connotation of trade secrets, administrative penalties for infringement of trade secrets, and civil compensation standards. On the one hand, it combines with the substantive law, such as the Labor Contract Law, the Criminal Law, the General Principles of the Civil Law, the Tort Liability Law, and the Contract Law, on the other hand, it combines with the procedural law ,such as the Criminal Procedure Law, the Civil Procedure Law, the Administrative Procedure Law, the Administrative Enforcement Law, the Administrative Punishment Law, and the Labor Dispute Mediation and Arbitration Law . These departmental laws constitute a legal protection system for trade secrets with Chinese characteristics, and adhere to Chinese legal characteristics and political characteristics.

Secondly, at the judicial level, China has comprehensively promoted the "three in one" trial system (Figure 1). The "three in one" of intellectual property trials refers to the unified trial of intellectual property civil, criminal and administrative cases by the intellectual property court of the people's court. In addition to the intellectual property courts in Beijing, Shanghai and Guangzhou, the "three-inone" work on intellectual property trials has been fully launched in China's senior, intermediate and grassroots courts. On January 1, 2019, the IP Court of the Supreme People's Court was formally listed, mainly dealing with professional and technical intellectual property civil and administrative appeal cases, including technical secret 
cases as the main content of trade secrets. China's recent series of legislative and judicial initiatives have fully demonstrated that the legal status of trade secrets in China's "new era" political context has become increasingly prominent, this is closely related to the promotion of the Special 301 Report as a unilateral referee policy for the United States to its international trading partners.

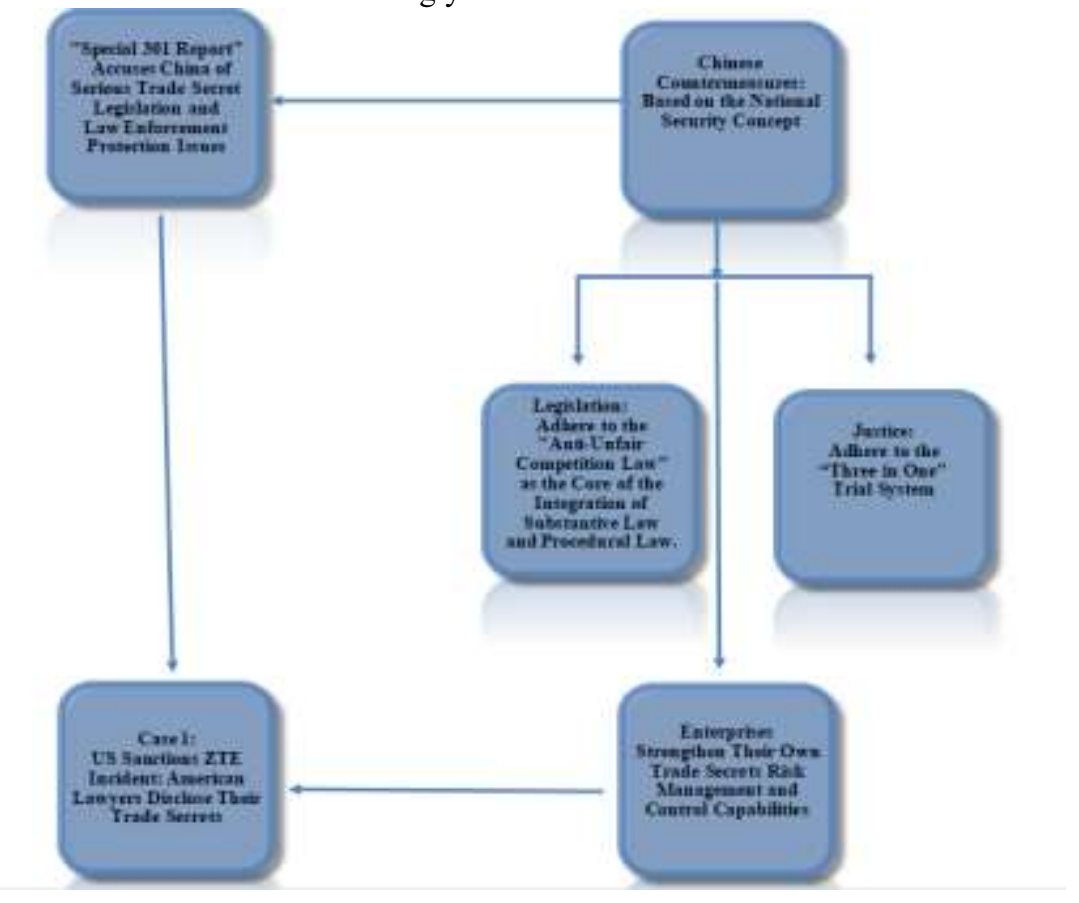

Figure 1 How to manage the legal risk of trade secrets

In short, from a positive perspective, the advanced management experience in commercial secret management of the United States provides a source of problems and a sound direction for the process of trade secret legislation and law enforcement of its many trading partners, including China. However, from a negative perspective, the position of this unilateral measure is centered on the interests of the United States and does not take into account the actual situation of its partners. As Lina M. Monten (2005) believes: unilateral measures such as the US Section 301 are not conducive to the long-term international protection of intellectual property rights, and will increase the hostility of trading partner countries that have not participated in the US unilateral policy negotiations and are forced to participate. The result of the assessment is that the cost of the United States is far greater than its benefits [2].

The issue of trade secrets, listed in the US Special 301 Report, can be used as a reference for the improvement of Chinese trade secret legislation and law enforcement, but it will never become a standard.

Third, the era positioning and response to the national security attributes of trade secrets.

The seminars on the main leading cadres at the provincial and ministerial level in China should adhere to the bottom line thinking and prevent the major risks from being resolved at the Central Party School on the morning of January 21, 2019. General Secretary of the CPC Central Committee, President of the State, and Chairman of the Central Military Commission Xi Jinping delivered an important speech at the opening ceremony: profoundly understand and accurately grasp the profound changes in the external environment and the new situations, new problems and new challenges facing China's reform, development and stability, and adhere to the bottom line thinking. Enhance the sense of urgency, improve the ability to prevent and control, and focus on preventing major risks. Party committees and governments at all levels must resolutely implement the overall national security concept and ensure China's political security [3]. Promote the governance of cybersecurity in accordance with the law, and the security of science and technology is an important part of national security. It is necessary to strengthen system construction and capacity building, improve the national innovation system, accelerate the construction of science and technology security early warning monitoring system, and accelerate the relevant legislative work in the fields of artificial intelligence, genetic editing, medical diagnosis, automatic driving, drones, and service robots.

In addition to raising the protection of trade secrets to the strategic level of national security in the Special $301 \mathrm{Re}-$ port, US President Trump signed an executive order on February 11, 2019 to launch the "American Artificial Intelligence Initiative", aimed at Mobilize more federal funds and resources for artificial intelligence research and development to meet the challenges of "strategic competitors and foreign competitors" and ensure the US's leading position in this field. This is the first time the US government has introduced a national-level artificial intelligence promotion program. In his White House statement, Trump 
stated that "the continued leadership of the United States in the field of artificial intelligence is critical to maintaining the US economy and national security [4]."

Whether it is China's overall national security concept or the US realist national security considerations, there is a relatively mature theoretical system as a support. Both countries believe that economic security is inseparable from national security. Therefore, in the Sino-US trade war, even if the two sides focus their contradictions on specific trade issues such as tariffs, intellectual property protection, subsidies, etc., relevant trade disputes will still be more or less implicated in national security issues [5]. This also explains from a point of view that for the issue of trade secrets in the Special 301 Report, China no longer regards it as a simple issue of intellectual property protection and legal liability, but incorporates it into the overall scope of the national security concept, to make overall considerations.

\section{CONCLUSION}

The "Special 301 Report" of the United States for many years is seriously dissatisfied with China's trade secret legislation and law enforcement management. It is believed that the Chinese government and the legislative judiciary have not paid attention to the protection of the rights of owners of foreign trade secrets such as the United States. The actual situation is that Chinese trade secrets have existed since ancient times. In China, they are called "secret recipes" or "cheats". They are self-protected by the right holders in their own way. The protection from the legal level starts late. However, under the general trend of world economic integration, China's politics, economy, and culture have developed at a rapid pace. China has also taken various measures of law and political governance to ensure the fruits of reform and opening up. China takes a rational approach to the US "Special 301 Report" and adheres to the combination of bilateral or multilateral consultation and self-improvement on the basis of respecting the reality of China's proposed business secrets, and properly resolves the legal regulation of China's trade secrets.

On May 17, 2016, Xi Jinping's speech at the Symposium on Philosophy and Social Science: To base on China, learn from foreign countries, and face the future, focus on building a philosophy and social science with Chinese characteristics, fully embodying Chinese characteristics, Chinese style.

The US Special 301 Report is a document that the US government provides policy support for its domestic laws. The proposed trade secrets issues and improvement measures for trading partner countries and China are based only on the generalization and summarization of extraterritorial economic interests of enterprises or individuals with trade secrets in the United States, with typical unilaterality and one-sidedness. China's existing business secret management system is based on the reality of China, supported by the legal system with Chinese characteristics, the foundation of national politics, and the role of the company itself. Reasonable response measures should be taken for the "Special 301 Report": The general problem for trade secrets can be perfected by the rule of law. For example, in the legislation, the combination of substantive law and procedural law is adopted. In the judicial process, the "three-in-one" trial method for the civil, administrative and criminal litigation of intellectual property courts is unified. These are the rule of law guarantee mode with Chinese characteristics. Relevant issues raised by the "Special 301 Report" based on US interests maybe it has some value for the Chinese legislation and enforcement of legal risk management and protection about trade secrets, but for China, should adhere to flexibly using bilateral or multilateral international negotiations or treaties, guided by the spirit of the above-mentioned speech by General Secretary Xi Jinping, from enterprises, the rule of law, politics, etc. Do a good job in managing the trade secrets of Chinese elements.

Since trade secrets are the core assets of all enterprises, the establishment of the management system of the enterprise itself is very important. While the state is enacting legislation and law enforcement on the issue of trade secrets, on the one hand, it must take into account the actual needs of the construction of the rule of law in the country and the objectively international political and economic exchanges, on the other hand, we must earnestly safeguard the trade secrets and interests of domestic enterprises. National legislation should help enterprises to better manage their trade secrets and protect their benign development while exercising the rule of law and political regulation of trade secrets.

\section{REFERENCES}

[1] Peter A, Petri, Michael G. (2019) Plummer: China should Join the New Trans-Pacific Partnership.

https://piie.com/system/files/documents/pb19-1.pdf.

[2] Lina M. Monten. (2005) The Inconsistency Between Section 301 and TRIPS: Counterproductive with Respect to the Future of International Protection of Intellectual Property Rights?

http://scholarship.law.marquette.edu/iplr/vol9/iss2/6.

[3] Xinhua Agency. (2020) Xi Jinping Delivered an Important Speech at the Opening Ceremony of the Main Seminars of the Provincial and Ministerial Level Leading Cadres Who Insisted on the Bottom Line Thinking and Focused on Preventing and Resolving Major Risks.

http://www.gov.cn/xinwen/2019-

01/21/content_5359898.htm.

[4] Xin Hua Net. (2019) Trump Signed the American Artificial Intelligence Development Initiative. 
http://www.xinhuanet.com//2019-

02/12/c_1124104751.htm.

[5] Peng Y. (2019) Security Exceptions in Sino-US Trade War. Journal of Wuhan University (Philosophy and Social Sciences Edition),2019(1):154-158. 